Daniel Karthe*, Tobias Reeh, Felix Kempf, Halim Lee, Edeltraud Guenther

\title{
Sustainable recovery of tourism in the post- COVID-19 world: Advocacy for a Resource Nexus perspective
}

https://doi.org/10.1515/tw-2021-0027

Abstract: The COVID-19 pandemic had unprecedented impacts on tourism worldwide, causing a major downturn in sectoral economic development and employment. Even though affected regions, businesses and customers are united in their hope of a rapid recovery, a return to business-as-usual is not desirable from an environmental perspective. The COVID-19 pandemic could, however, also be an opportunity for sustainability-oriented transformations in various segments of the tourist industry. A concept that has received growing attention in sustainability science and policy but that has not yet been applied to tourism may have a significant future potential here: the Resource Nexus. As a consistent and application-oriented framework for the integrated management of environmental resources, the Resource Nexus can be a model for advancing sustainability in tourism. Instead of looking at a single dimension only, the Resource Nexus considers environmental resources in a holistic way, including potential synergies and trade-offs between different development goals. This can ultimately support a transition not only to more sustainability, but also to greater resilience of the tourism sector against environmental changes.

\footnotetext{
*Corresponding author: Daniel Karthe, United Nations University - Institute for Integrated Management of Material Fluxes and of Resources (UNU-FLORES), Ammonstr. 74, D-01067 Dresden, E-Mail: karthe@unu.edu; co-affiliated to Technische Universität Dresden, Faculty of Environmental Sciences, D-01062 Dresden, and German-Mongolian Institute for Resources and Technology (GMIT), Engineering Faculty, Ulaanbaatar 12790, Mongolia

Tobias Reeh, Georg-August-Universität Göttingen, Institute of Geography, Goldschmidtstr. 5, D-37077 Göttingen, E-Mail: treeh@gwdg.de

Felix Kempf, IST University of Applied Sciences, Faculty of Tourism and Hospitality, Erkrather Str. 220 a-c, D-40233 Düsseldorf, E-Mail: FKempf@ist-hochschule.de

Halim Lee, United Nations University - Institute for Integrated Management of Material Fluxes and of Resources (UNU-FLORES), Ammonstr. 74, D-01067 Dresden, E-Mail: halim.lee@unu.edu Edeltraud Guenther, United Nations University - Institute for Integrated Management of Material Fluxes and of Resources (UNU-FLORES), Ammonstr. 74, D-01067 Dresden, E-Mail: guenther@unu.edu; co-affiliated to Technische Universität Dresden, Faculty of Business and Economics, D-01062 Dresden
} 
Keywords: COVID-19, Environmental Impacts, Sustainable Tourism, Resource Nexus

Zusammenfassung: Die COVID-19-Pandemie hatte weltweit beispiellose Auswirkungen auf den Tourismus und verursachte einen erheblichen Rückgang der sektoralen wirtschaftlichen Entwicklung und Beschäftigung. Auch wenn sich betroffene Regionen, Unternehmen und Kunden in der Hoffnung auf eine rasche Erholung einig sind, ist eine Rückkehr zum „Business-as-usual“ aus ökologischer Sicht nicht wünschenswert. Die COVID-19 Pandemie könnte somit auch eine Chance für nachhaltigkeitsorientierte Transformationen in verschiedenen Bereichen der Tourismusbranche sein. Ein Konzept, das in der Nachhaltigkeitswissenschaft und -politik wachsende Aufmerksamkeit erregt hat, aber noch nicht auf den Tourismus angewendet wurde, dürfte hier ein erhebliches Zukunftspotenzial haben: der Ressourcen-Nexus. Dieser Ansatz bietet einen konsistenten und anwendungsorientierten Rahmen für das integrierte Management von Umweltressourcen auch im Tourismus. Anstatt nur eine einzelne Dimension zu betrachten, erfasst der Nexus Umweltressourcen ganzheitlich, einschließlich potenzieller Synergien und Konflikten zwischen verschiedenen Entwicklungszielen. Dies kann letztlich nicht nur zu mehr Nachhaltigkeit, sondern auch zu einer größeren Resilienz des Tourismussektors gegenüber Umweltveränderungen beitragen.

Schlüsselwörter: COVID-19, Umweltbelastung, Nachhaltiger Tourismus, Ressourcen-Nexus

\section{Introduction}

In early 2020, fears related to the global spread of the COVID-19 pandemic led to an unprecedented decline in global tourism and long-lasting border closures in many countries (Gössling et al., 2021). In a short-term perspective, this significantly reduced the sector's environmental footprint, whereas the long-term impacts of the pandemic are less clear. Even though some academics predict a return of the industry to "business as usual", trying to overcompensate for lost revenue, others consider the pandemic as an opportunity for a sustainability-oriented transformation (Higgins-Desbiolles, 2020). We advocate for shaping this transformation by applying a Resource Nexus approach that considers all environmental compartments and their interlinkages. Based on a short summary of the current state of the art regarding the Resource Nexus approach (section 2), we 
outline the rationale and potentials of applying the Resource Nexus concept in the field of tourism research and management (section 3).

\section{The Resource Nexus concept}

Based on holistic approaches in environmental resources management such as integrated water resources management (IWRM) or integrated land management (Karthe et al., 2021; Roidt \& Avellán, 2019), environmental nexus approaches go one step further by considering linkages between several resources or environmental compartments without prioritizing one of them. First popularized by the Bonn Nexus Conference in 2011 (Hoff, 2011), the Resource Nexus approach considers interdependencies of environmental resources, which may translate into synergies or tradeoffs between different management goals (Constanza \& Kubiszewski, 2016). At the same time, the Resource Nexus has multiple linkages to Sustainable Development, and many of the Nexus goals are connected to the sustainable development goals (Bleischwitz et al., 2018). In this way, the Resource Nexus approaches can go beyond a purely environmental perspective and align environmental sustainability with sustainable socio-economic development. With its focus on primary and secondary environmental resources including water, raw materials, soil, biodiversity, food, energy and waste, the Resource Nexus follows the key principle of rethinking economic growth based on ever-increasing resource consumption (Purwanto et al., 2021) that is also characteristic for contemporary mass tourism. The concept is therefore increasingly used to guide institutional or policy responses towards problems in resource management (Albrecht et al., 2018; Cremades et al., 2019; Dai et al., 2018). As the Resource Nexus considers intersections between environmental sciences, engineering, economics, political ecology, and other social sciences, it allows for systemic analyses (D’Odorico et al., 2018) and provides the opportunity to dissolve disciplinary divides and sectoral barriers (Endo et al., 2017).

\section{Advocating a Resource Nexus approach to sustainable tourism development}

Tourism contributes to several global change phenomena that are characteristic of the Anthropocene (Steffen et al., 2015), including climate change, soil degradation, water pollution, waste generation, land use change and biodiversity loss 
at the local, regional, and planetary scale (Eijgelaar \& Peters, 2014). It is therefore not surprising that according to scientometric analyses, the ecological footprint of tourism, overtourism and the planet's carrying capacity have developed into important topics in tourism research worldwide (Zhang et al., 2015). Moreover, this topic is not only discussed in research but also implemented in tourism practice. For example, the World Tourism Organization launched a programme on "building back better" tourism in the wake of the COVID-19 pandemic (UN-WTO, 2020). Despite the multiple negative impacts that tourism has on the environment, it is important to note that tourism often provides a budget and motivation for nature protection (Sumanapala \& Wolf, 2020) and can thus promote and advance environmental preservation or rehabilitation.

As tourism can have positive and negative impacts on multiple environmental resources, integrated approaches such as that on the Resource Nexus are meaningful, particularly when combined with the sustainable development goals (Figure 1). The goals of the Resource Nexus are similar to the 'planetary SDGs' (i.e. those goals that contain environmental objectives) while at the same time highlighting interconnections between different environmental dimensions.

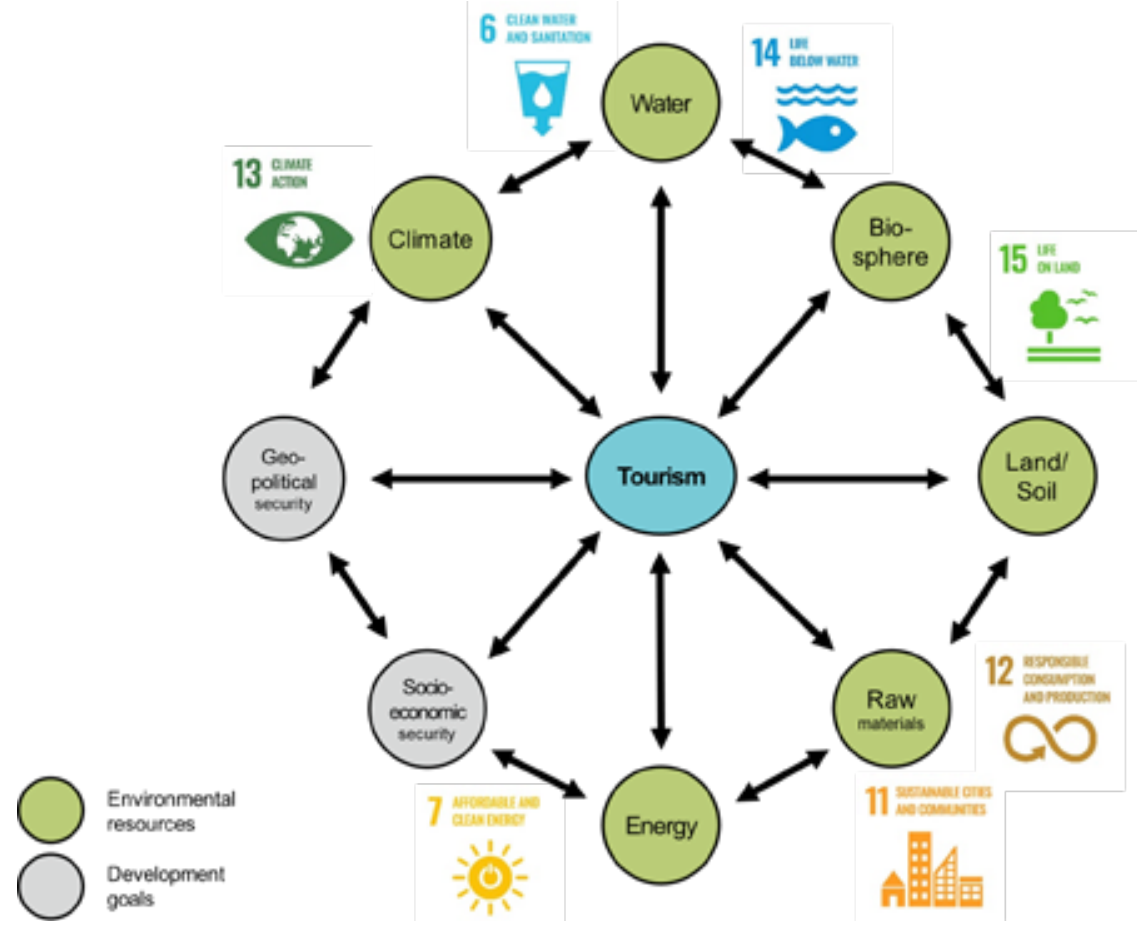

Figure 1: Linkages between tourism, natural resources and the 'planetary' SDGs. 
Only very few examples of Nexus applications exist in the tourism context so far, and none of them considered a fully-fledged Resource Nexus perspective. Khan et al. (2020) investigated the nexus between tourism development and sectoral energy usage and climate-relevant emissions for 51 Belt- and-Road Initiative countries. The authors highlighted that more investment on sustainable infrastructure is fundamental to improve not only environmental quality, but also the resilience of tourism. For the field of tourist accommodation, Becken \& McLennan (2017) analyzed the nexus between water, energy and waste and identified synergies for the management of the three resources. In a similar study on the accommodation sector and recreational activities in the popular Spanish destination of Benidorm, Yoon et al. (2021) revealed significant interlinkages between the water and energy sectors (i. e. "hidden" energy usage for water provision and "hidden" water usage for energy provision). On this basis, they concluded that for tourism as a significant water and energy user, efforts to save one of these resources also has positive effects for the other one. Despite some first studies and the theoretical potential of the Resource Nexus approach in tourism, both analytical and practical examples of using this concept are only at their beginning. In order to turn tourism into a driver of sustainable development, it is necessary to take even more integrated approaches than previous research did. Ultimately, it is necessary to consider all (positive and negative) environmental impacts of tourism (Figure 2).

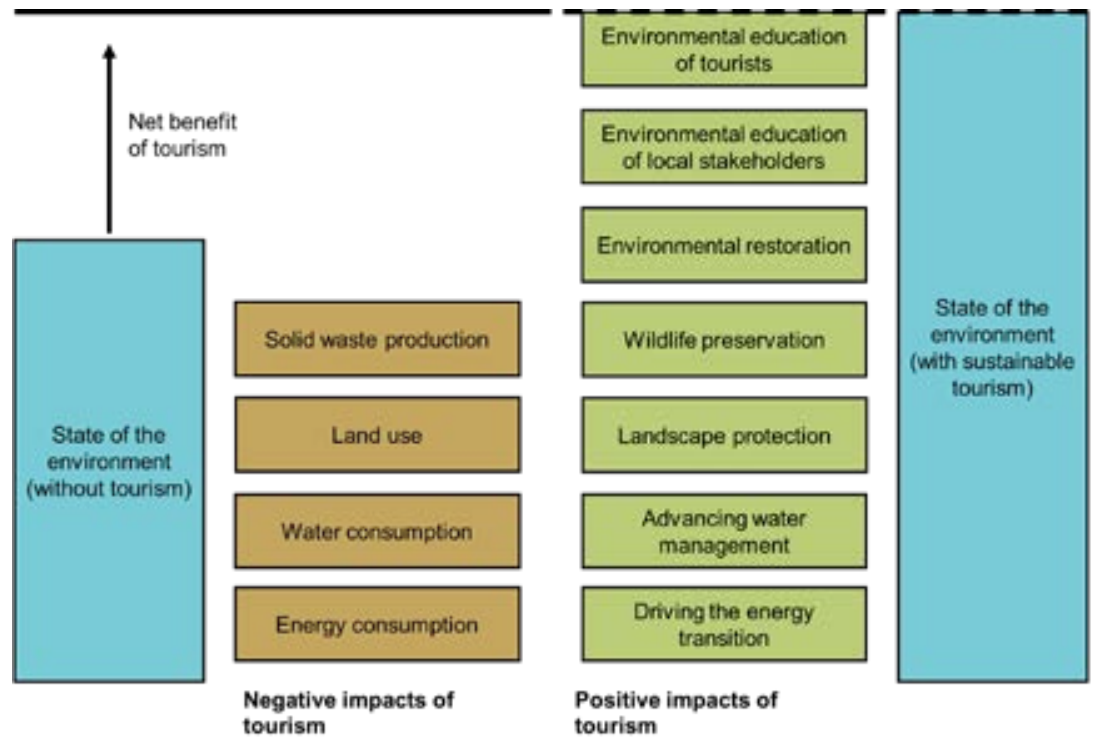

Figure 2: Conceptual Environmental net benefits from tourism 
From a management perspective, strategies should aim not only at minimizing the negative impacts of tourism, but also at maximizing the positive effects that tourism can have for the environment. In the end, the positive effects would ideally outweigh the negative impacts, leading to a 'net benefit' of tourism. As different environmental effects are often interrelated, it is meaningful to apply Resource Nexus approaches for integrated environmental impact assessments and the management measures based on them. This can ultimately help to go beyond resource-specific perspectives (e.g., reduction of carbon footprints) and integrate them in more holistic sustainable development strategies. Against this background, we advocate for a more widespread usage of Resource Nexus approaches for sustainability assessment and management in the tourism sector.

\section{References}

Albrecht, T. R., Crootof, A., \& Scott, C. A. (2018). The Water-Energy-Food Nexus: A systematic review of methods for nexus assessment. Environmental Research Letters, 13 (4), 043002. https://doi.org/10.1088/1748-9326/aaa9c6

Becken, S., \& McLennan, C. L. (2017). Evidence of the water-energy nexus in tourist accommodation. Journal of Cleaner Production, 144, 415-425. https://doi.org/10.1016/ j.jclepro.2016.12.167

Bleischwitz, R., Spataru, C., VanDeveer, S. D., Obersteiner, M., van der Voet, E., Johnson, C., Andrews-Speed, P., Boersma, T., Hoff, H., \& van Vuuren, D. P. (2018). Resource nexus perspectives towards the United Nations Sustainable Development Goals. Nature Sustainability, 1 (12), 737-743. https://doi.org/10.1038/s41893-018-0173-2

Constanza, R., \& Kubiszewski, I. (2016). A Nexus Approach to Urban and Regional Planning Using the Four-Capital Framework of Ecological Economics. In: Hettiarachchi, H., \& Ardakanian, R. (Eds.), Environmental Resource Management and the Nexus Approach, (pp. 79-111). Cham, Switzerland: Springer.

Cremades, R., Mitter, H., Tudose, N. C., Sanchez-Plaza, A., Graves, A., Broekman, A., Bender, S., Giupponi, C., Koundouri, P., Bahri, M., Cheval, S., Cortekar, J., Moreno, Y., Melo, O., Karner, K., Ungurean, C., Davidescu, S. O., Kropf, B., Brouwer, F., \& Marin, M. (2019). Ten principles to integrate the water-energy-land nexus with climate services for co-producing local and regional integrated assessments. Science of the Total Environment, 693, 133662. https://doi.org/10.1016/j.scitotenv.2019.133662

Dai, J., Wu, S., Han, G., Weinberg, J., Xie, X., Wu, X., Song, X., Jia, B., Xue, W., \& Yang, Q. (2018). Water-energy nexus: A review of methods and tools for macro-assessment. Applied energy, 210, 393-408. https://doi.org/10.1016/j.apenergy.2017.08.243

D’Odorico, P., Davis, K. F., Rosa, L., Carr, J. A., Chiarelli, D., Dell'Angelo, J., Gephart J., MacDonald, G., Seekell, D. A., Suweis, S., \& Rulli, M. C. (2018). The global food-energy-water nexus. Reviews of geophysics, 56 (3), 456-531. https://doi.org/10.1029/2017RG000591

Eijgelaar, E., \& Peeters, P. (2014). The Global Footprint of Tourism. In: Lew, A. A., Hall, C. M., \& Williams, A. M. (Eds.), The Wiley Blackwell Companion to Tourism (pp. 454-465). Chichester, UK: John Wiley \& Sons. 
Endo, A., Tsurita, I., Burnett, K., \& Orencio, P. M. (2017). A review of the current state of research on the water, energy, and food nexus. Journal of Hydrology: Regional Studies, 11, 20-30. https://doi.org/10.1016/j.ejrh.2015.11.010

Gössling, S., Scott, D., \& Hall, C.M. (2021). Pandemics, tourism and global change: a rapid assessment of COVID-19. Journal of Sustainable Tourism, 29 (1), 1-20. https://doi.org/ 10.1080/09669582.2020.1758708

Higgins-Desbiolles, F. (2021). The "war over tourism": challenges to sustainable tourism in the tourism academy after COVID-19. Journal of Sustainable Tourism, 29 (4), 551-569. https:// doi.org/10.1080/09669582.2020.1803334

Hoff, H. (2011). Understanding the nexus. Background Paper for the Bonn 2011 Conference: The Water, Energy and Food Security Nexus. Stockholm, Sweden: Stockholm Environment Institute.

Karthe, D., Bogardi, J., \& Borchardt, D. (2021). Water resources management: integrated and adaptive decision making. In: Bogardi, J. J., Tingsanchali, T., Nandalal, K. D. W., Gupta, J., Salamé, L., van Nooijen, R. R. P., Kolechkina, A. G., Kumar, N., \& Bhaduri, A. (Eds.), Handbook of Water Resources Management: Discourses, Concepts and Examples (pp. 365-381). Cham, Switzerland: Springer.

Khan, A., Chenggang, Y., Hussain, J., Bano, S., \& Nawaz, A. (2020). Natural resources, tourism development, and energy-growth- $\mathrm{CO}_{2}$ emission nexus: A simultaneity modeling analysis of BRI countries. Resources Policy, 68, 101751. https://doi.org/10.1016/j.resourpol.2020. 101751

Purwanto, A., Sušnik, J., Suryadi, F. X., \& Fraiture, C. D. (2021). Water-energy-food nexus: Critical review, practical applications, and prospects for future research. Sustainability, 13 (4), 1919. https://doi.org/10.3390/su13041919

Roidt, M., \& Avellán, T. (2019). Learning from integrated management approaches to implement the Nexus. Journal of Environmental Management, 237, 609-616. https://doi.org/10.1016/j.jenvman.2019.02.106

Steffen, W., Broadgate, W., Deutsch, L., Gaffney, O., \& Ludwig, C. (2015). The trajectory of the Anthropocene: The Great Acceleration. The Anthropocene Review, 2 (1), 1-18. https://doi.org/10.1073/pnas.1810141115

Sumanapala, D., \& Wolf, I. D. (2020). Think globally, act locally: Current understanding and future directions for nature-based tourism research in Sri Lanka. Journal of Hospitality and Tourism Management, 45, 295-308. https://doi.org/10.1016/j.jhtm.2020.08.009

United Nations World Tourism Organization (=UN-WTO) (2020). Building Back Better in Tourism: The roles of international organizations. Tourism and COVID-19. Retrieved from https://www.wto.org/english/tratop_e/serv_e/simply_services_zoritsa_23jan_2020.pdf (Accessed 31 May 2021)

Yoon, H., Sauri, D., \& Rico, A. (2021). The water-energy nexus in hotels and recreational activities of a mass tourism resort: the case of Benidorm. Current Issues in Tourism, https://doi.org/10.1080/13683500.2021.1893283

Zhang, S., Lyu, P., \& Yan, Y. (2015). Global geographical and scientometric analysis of tourismthemed research. Scientometrics, 105, 385-401. https://doi.org/10.1007/s11192-015$1678-3$ 


\section{Authors' Information}

\section{Daniel Karthe}

United Nations University - Institute for Integrated Management of Material Fluxes and of

Resources (UNU-FLORES)

Ammonstr. 74, D-01067 Dresden

E-Mail: karthe@unu.edu

co-affiliated to Technische Universität Dresden, Faculty of Environmental Sciences

D-01062 Dresden

German-Mongolian Institute for Resources and Technology (GMIT)

Engineering Faculty

Ulaanbaatar 12790, Mongolia

Daniel Karthe heads the research programme 'Resource Nexus for Regions in Transformation' at UNU-FLORES, Dresden, Germany. He is a co-appointed member of the Faculty of Environmental Sciences at TU Dresden and holds a professorship in Environmental Engineering at the German-Mongolian Institute for Resources and Technology. His research interests focus on environmental sustainability and management, including the Resource Nexus.

\section{Tobias Reeh}

Georg-August-Universität Göttingen

Institute of Geography

Goldschmidtstr. 5, D-37077 Göttingen

E-Mail: treeh@gwdg.de

Tobias Reeh is a lecturer in the Department of Geography at Georg-August-University, Göttingen, Germany. His main research interests include sustainable tourism, ethnic groups, heritage interpretation, environmental history and geographical education. He is the managing director of the Centre for Environmental Interpretation and Tourism and a member of the working group on Tourism Geography within German Geographical Society (AKTF) as well as the German Society of Tourism Research (DGT).

\section{Felix Kempf}

IST University of Applied Sciences

Faculty of Tourism and Hospitality

Erkrather Str. 220 a-c, D-40233 Düsseldorf

E-Mail: FKempf@ist-hochschule.de

Felix Kempf is Dean of the Faculty of Tourism and Hospitality at IST University of Applied Sciences in Düsseldorf, Germany. His research focuses on inclusive tourism with a particular focus on persons with disabilities, considering both customers and the tourism workforce. $\mathrm{He}$ is member of Germany's leading German tourism research organizations (DGT and AKTF) and the Green Party of Germany. 


\section{Halim Lee}

United Nations University - Institute for Integrated Management of Material Fluxes and of Resources (UNU-FLORES)

Ammonstr. 74, D-01067 Dresden

E-Mail: halim.lee@unu.edu

Halim Lee is a Senior Research Assistant at UNU-FLORES. She worked as a researcher at the Environmental GIS/RS Laboratory in Korea University in Republic of Korea. She previously served as a programme support intern at United Nations Environment Programme (UNEP), Switzerland. Her research interests include the Resource Nexus with a particular focus on sustainable development and environmental resources.

\section{Edeltraud Guenther}

United Nations University - Institute for Integrated Management of Material Fluxes and of Resources (UNU-FLORES)

Ammonstr. 74, D-01067 Dresden

E-Mail: guenther@unu.edu

co-affiliated to Technische Universität Dresden

Faculty of Business and Economics

D-01062 Dresden

Edeltraud Guenther is Director of UNU-FLORES and has been holding the Chair of Business Management esp. Sustainability Management and Environmental Accounting at TU Dresden since 1996. She held Visiting Professorships at Namibia University of Science and Technology (NUST), Kobe University, and University of Virginia. Her research focuses on sustainability management, environmental accounting, and management control systems, with an emphasis on corporate responsibility, life cycle assessment, resilience, and sustainability assessment. 